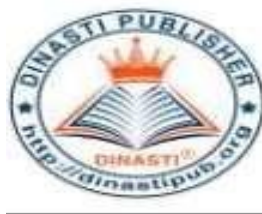

\title{
THE EFFECT OF ORGANIZATIONAL COMMUNICATION AND JOB SATISFACTION ON EMPLOYEE ENGAGEMENT AND EMPLOYEE PERFORMANCE AT PT. ABYOR INTERNATIONAL
}

\author{
Febrial, Eka ${ }^{1)}$, Herminingsih, Anik ${ }^{2)}$
}

${ }^{1,2)}$ Mercu Buana University, Jakarta, Indonesia

ARTICLE INFORMATION

Received: $21^{\text {st }}$ March 2020

Revised: $1^{\text {st }}$ April 2020

Issued: $16^{\text {th }}$ April 2020

Corresponding author:

Febrial Eka

E-mail:

eka.febrial@live.com

anik.herminingsih@mercubuana.ac.id

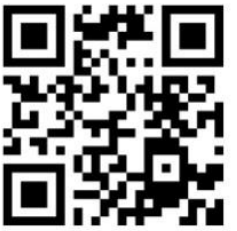

DOI:10.31933/DIJEMSS
Abstract: This study aims to analyze the effect of organizational communication and job satisfaction, on employee engagement and employee performance. The research data used are primary data derived from questionnaires and secondary data derived from company data. The sample method used is the nonprobability method. The population comes from all employees of PT. Abyor International which is still active in September 2019. The analytical method used in this study is the Partial Least Square (PLS) Structured Equation Model (SEM) using Smart PLS version 3.0. The results showed that organizational communication and job satisfaction had a positive and significant effect to employee engagement. Organizational communication and job satisfaction have no significant effect to employee performance. Employee engagement has a positive and significant effect to employee performance. Employee engagement becomes mediator for organizational communication and job satisfaction variables in influencing employee performance.

Keywords: organizational communication, job satisfaction,employee engagement, employee performance.

\section{INTRODUCTION}

Organizations which have high performance and able to survive in sustainability with prosperous conditions are the one that focus on managing human resources in proactive and systematic way (Berger and Berger, 2004). Any organization that has high performance, has a high level of employee engagement (Noe et al., 2014). Employee engagement is defined as the extent to which employees are fully involved in their work and the strength of their commitment to their work and the organization.

Many organizations are concerned about the engagement level of their employees, because the employees with high engagement can work with extra miles to produce the best performance and have a high commitment to stay in the organizations (Vance, 2006). PT. Abyor International (Abyor) is one of the Information Technology Services Company which has a high concern on their employee engagement and performance. The results of internal employee engagement survey 2018 indicate this engagement problem, where the survey response rate only achieve $69 \%$ from the expected rate of $75 \%$. 
Results of interviews conducted with General Manager of Corporate Services Division which oversees Human Resources highlight some parameter as the concern in the company's performance: consultant utilization rate, and sales revenue target. Consultant utilization rate was only by $87 \%$ in 2017 and by $70 \%$ in 2018, below the target of $90 \%$ rate. Sales revenue achievement was by $62 \%$ in 2017 , and by $69 \%$ in 2018 , while management expect to meet $100 \%$ target. The pre-survey results indicate that there are indications of performance problems, employee engagement, organizational citizenship behavior, organizational communication and job satisfaction at Abyor. From the indications of the problem, the author take several variables to be examined: organizational communication, job satisfaction, employee engagement, and employee performance.

Furthermore, there are differences in the results of some previous studies between organizational communication, job satisfaction, employee engagement, and employee performance. Based on the description above, author will do research on " The Effect of Organizational Communication and Job Satisfaction on Employee Engagement and Employee Performance at PT. Abyor International ".

Considering all the research problem formulation outlined above, the objectives to be achieved in this study are to analyze and explain: (1) the effect of organizational communication on employee engagement at Abyor; (2) the effect of job satisfaction on employee engagement at Abyor; (3) the influence of employee engagement on employee performance at Abyor; (4) the effect of organizational communication on employee performance at Abyor; (5) the effect of job satisfaction on employee performance at Abyor; (6) the role of employee engagement in mediating the effect of organizational communication on employee performance at Abyor; (7) the role of employee engagement in mediating the effect of job satisfaction on employee performance at Abyor.

\section{LITERATURE REVIEW}

\section{Organizational Communication}

Robbins and Coulter (2018) define communication as a transfer and understanding of meaning, so that communication is said to be successful if the meaning of the information has been conveyed and understood by the recipient exactly as imagined by the sender. Communication includes interpersonal communication (between two or more people) and organizational communication, which is all patterns, networks, and communication systems in an organization. Communication programs within organizations are needed when an organization is getting bigger and more complex, with the aim of keeping the team in it able to keep working effectively achieving organizational goals (Gillis et al., 2006). From the above definition, it can be concluded that organizational communication is the patterns, networks, and communication systems in an organization which is designed with the aim of keeping the organization's member working effectively achieving organizational goals.

\section{Job Satisfaction}

According to Armstrong \& Taylor (2014) job satisfaction is the attitudes and feelings people have about their work. In this case, a positive and pleasant attitude towards work indicates job satisfaction, and a negative and unpleasant attitude toward work indicates job dissatisfaction. Similarly, Noe et al. (2016) define job satisfaction as a pleasant feeling that results from the perception that a person's job fulfills or allows for the fulfillment of work values that are important to him/her. Organizations want to prevent employees from experiencing job-withdrawal behavior, which is a set of behaviors that employees use to avoid work situations physically, mentally, or emotionally. The driving force behind job-withdrawal is job dissatisfaction. Based on some of the opinions above, it can be concluded that job 
satisfaction is a positive and pleasant attitude towards a person's job, that results from the perception that the job can fulfill some values that are important to him/her.

\section{Employee Engagement}

MacLeod and Clarke (2009) see employee engagement as an approach in the workplace that is designed to ensure that employees are willing to commit to their organizational values and goals, are motivated to contribute to organizational success, and are able to increase their sense of ownership in the organization simultaneously. According to Schaufeli, et al. (2006), engagement is defined as feeling positive, satisfied, and very attached to the work shown by aspects of vigor, dedication, and absorption. Employee engagement is also defined as a condition where employees feel satisfaction, enthusiasm, and close ties with their work (Vance, 2006). Based on some of the above notions, it can be concluded that employee engagement is the condition where employee has the sense of satisfaction, enthusiasm, and commitment to their organizational values and goals, which will motivate him/her to contribute to organizational success.

\section{Employee Performance}

Dessler (2018) defines performance as work performance, namely the comparison between work results and established standards. According to Mathis and Jackson (2015), employee performance is what influences how much they contribute to the organization. Furthermore, Armstrong (2006) said that employee performance should not only be measured by what has been achieved, but how it is achieved. Summarizing the notions above, employee performance is the success level of employee in delivering their work tasks stated in established standards which contribute to the organization success, measured by the results and processes.

\section{Theoretical framework}

Research conducted by Psychometrics (2011) revealed that organizational communication has a close relationship with employee engagement and are one of the factors that influence it. In relations with that, several studies found that organizational communication is one of the factors that influence employee performance (Madhura and Pandita, 2014; Baba, 2014).

Based on previous research, it was found that job satisfaction affects an employee's engagement with his organization (Herminingsih, 2017; Shmailan, 2016). Furthermore, some research shows that job satisfaction has a significant effect on employee performance (Berliana, et al, 2018; Bakotic, 2016). The significant influence of engagement on employee performance is supported by previous studies such as Ariyanto (2018), and Osborne and Hammoud (2017). Based on the explanation of the relationship between the variables described above, author composes a conceptual framework shown in Figure 1. 


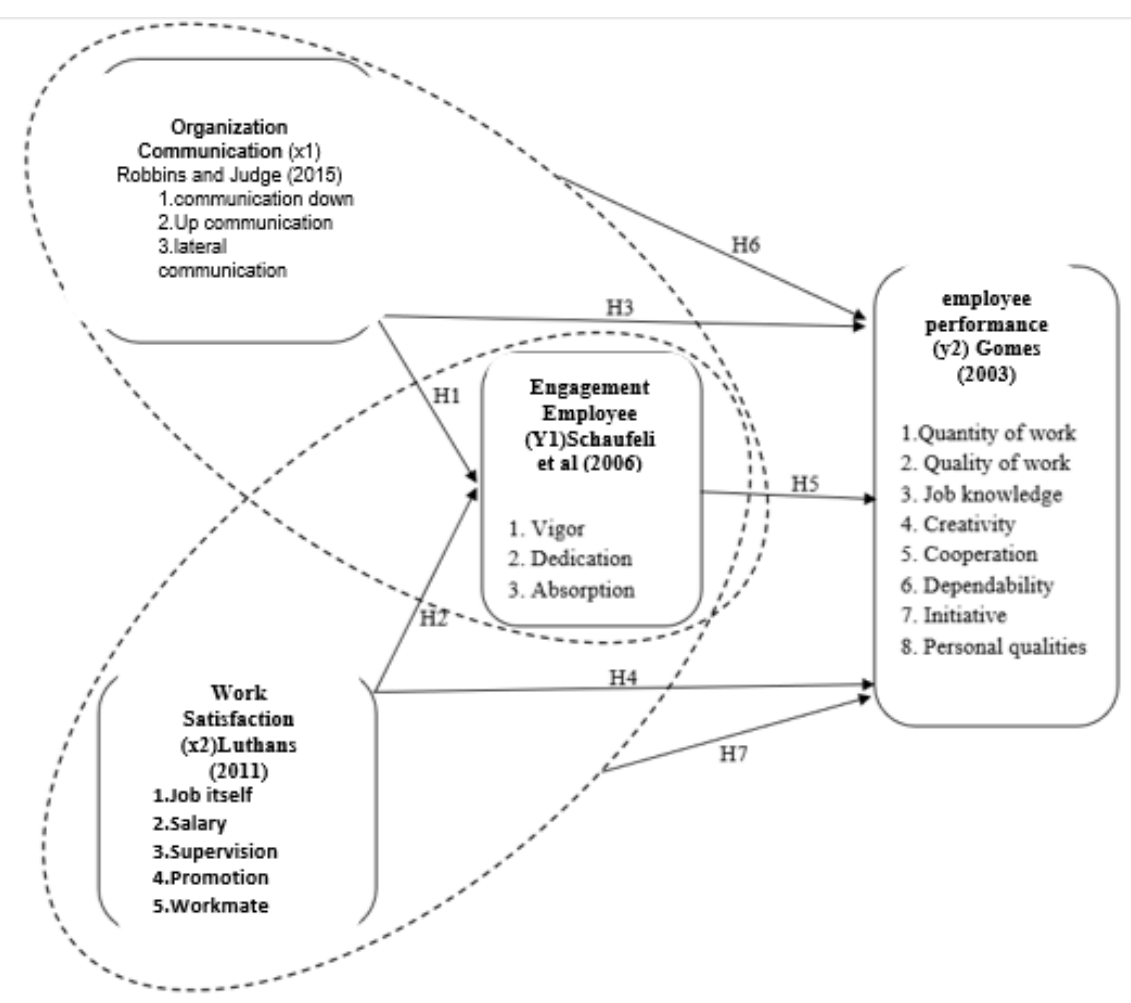

\section{Hypothesis}

Figure 1. Conceptual Framework

Refer to the research objectives, theoretical basis and the formulation of the problem described above, the hypotheses proposed in this research are as follows:

H1: Organizational communication has a positive effect on employee engagement.

$\mathrm{H} 2$ : Job satisfaction has a positive effect on employee engagement.

H3: Organizational communication has a positive effect on employee performance.

H4: Job satisfaction has a positive effect on employee performance.

H5: Employee engagement has a positive effect on employee performance.

H6:Employee engagement has a significant influence in mediating the effect of organizational communication on employee performance.

H7: Employee engagement has a significant influence in mediating the effect of job satisfaction on employee performance.

\section{RESEARCH METHODS}

This type of research is quantitative research using primary data in the form of surveys. This study was designed with the aim of being able to understand, explain, and analyze the correlation between the independent variables and the dependent variables.

\section{FINDINGS AND DISCUSSION}

The results of this study will be explained by descriptive statistics and inferential statistics using secondary data and primary data obtained during the study.

\section{Evaluation of Measurement Model (Outer Model)}

Evaluation is done to find out the validity and reliability that links between indicators with latent variables. The loading factor value used in this study is above 0.5 , and if found indicator with loading factor below 0,5 in the calculation, it will be excluded from the model. The higher the loading factor, the more important the role of the indicator will be in interpreting 
the variables. Refer to the result, all loading factor value from all variables are above 0.5 as shown in Figure 2, Figure 3, Figure 4, and Figure 5.

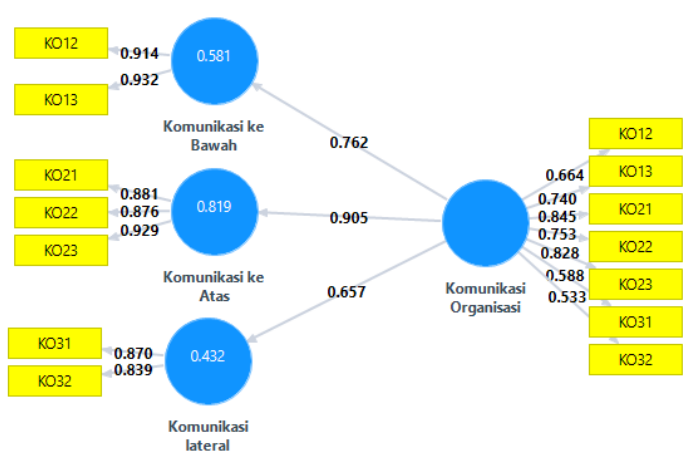

Figure 2. Outer Model Organizational Communication

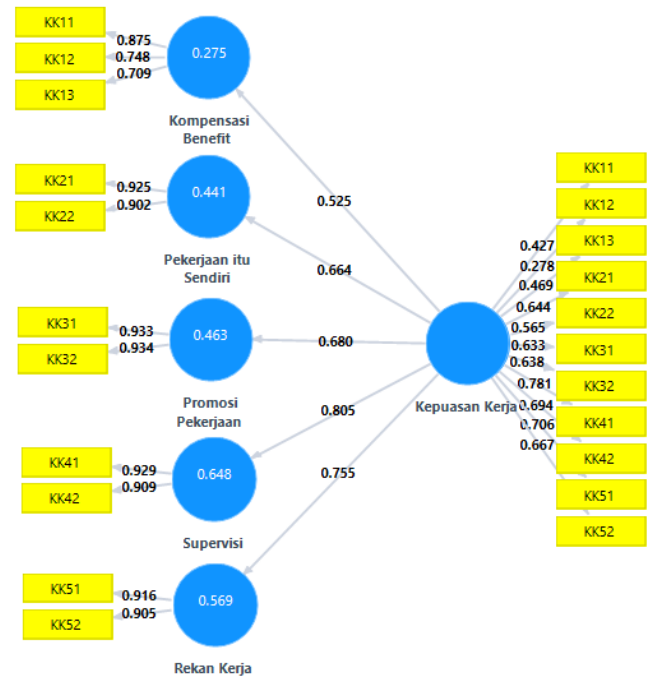

Figure 3. Outer Model Job Satisfaction

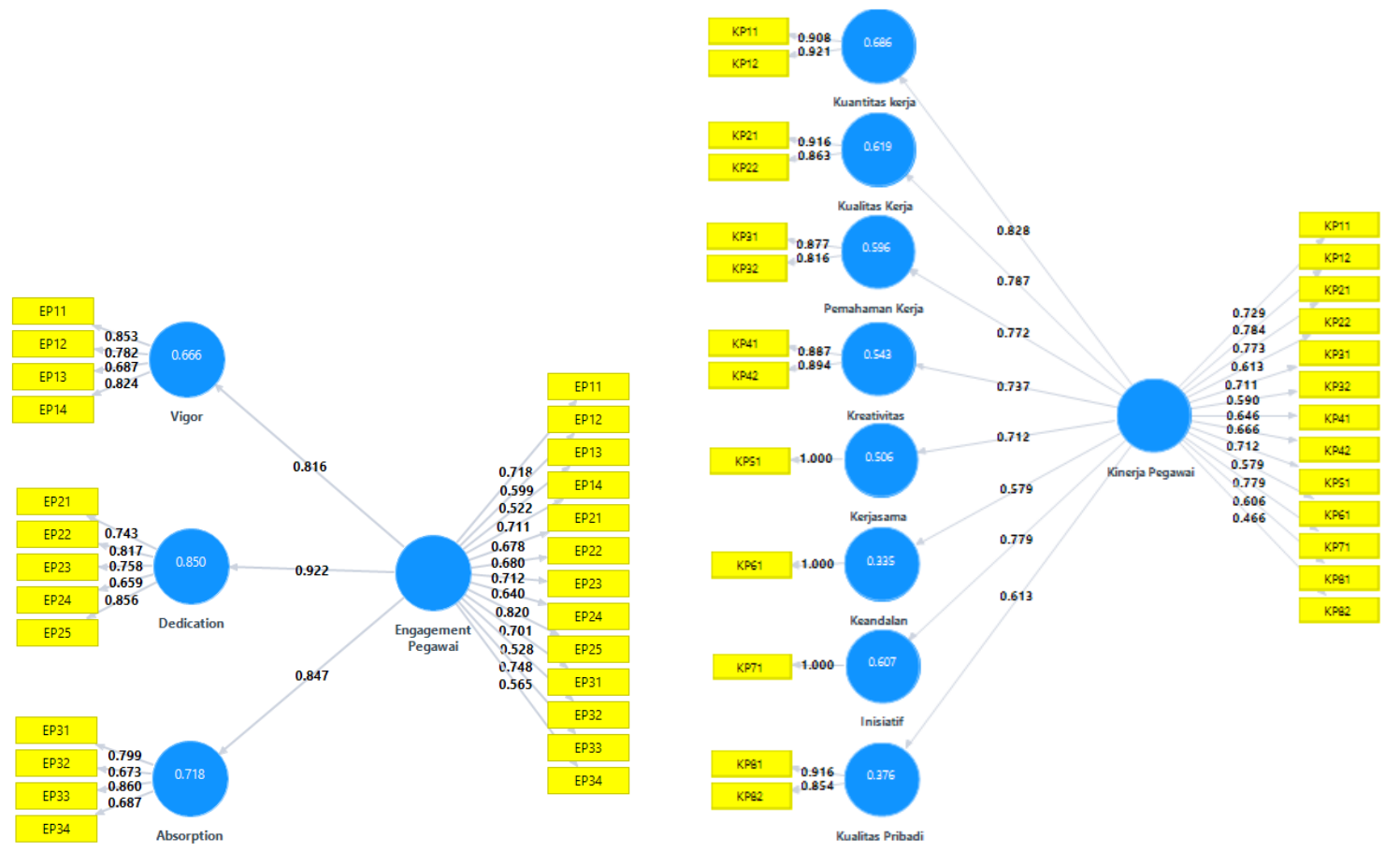

Figure 4. Outer Model Employee Engagement Figure 5. Outer Model Employee Performance

Likewise, the AVE value is also used as an indicator of the assessment of convergent validity. According to Hair et. al. (2014) the AVE value must be >0.5, Table 2 shows the AVE value. AVE value of all variables are above 0.5 , except for the variable of job satisfaction, which is equal to 0.462 . The AVE values below 0.5 can be caused by the minimum number of samples, so that the response variants from respondents produce errors. In this study, the number of samples was very minimum, which is 71 people. 
Table 2. Value of AVE, Cronbach Alpha, and Composite Reliability (CR)

\begin{tabular}{|c|c|c|c|}
\hline Variable & AVE & Cronbach's Alpha & Composite Reliability \\
\hline Organizational Communication & 0.610 & 0.683 & 0.825 \\
\hline Job Satisfaction & 0.462 & 0.714 & 0.801 \\
\hline Employee Engagement & 0.737 & 0.821 & 0.894 \\
\hline Employee Performance & 0.530 & 0.871 & 0.899 \\
\hline
\end{tabular}

Source: Researcher processed data (2019)

Evaluation of convergent validity from internal consistency reliability checks can be seen from the Cronbach's Coefficient Alpha and Composite Reliability (CR) values shown in the Table 2. As seen in Table 2, it is known that the Cronbach's Alpha value and Composite Reliability value for all research variables are more than 0.80 . These values have exceeded the standard, respectively $>0.6$ for Cronbach's Alpha, and > 0.7 for Composite Reliability. Summarize on the result, all variables in the study are declared to be reliable. In the result of discriminant validity evaluation, found an indicator with a low cross-loading value, that is an indicator of organizational communication variables: downward communication dimension (KO11). After deletion, all indicators have valid cross-loading values.

\section{Evaluation of Structural Model ( Inner Model )}

Colinearity testing at the variable level is needed to see that there is no high correlation between the constituent variables performed using the Variance Inflator Factor (VIF) value, with the value of less than 5. The results of data processing found VIF values of all dimensions less than 5, which indicates that there is no high correlation between the variables making up the path model in this study. Calculations using SmartPLS version 3.2.8 bootstrapping showed the path coefficients which describes the strength of the relationship between the constructs, as shown in Table 4.

Table 4. Significance of Coefficient Path

\begin{tabular}{lcccc}
\hline \multicolumn{1}{c}{ Path } & $\begin{array}{c}\text { Original } \\
\text { Sample }\end{array}$ & $\begin{array}{c}\mathrm{t} \\
\text { statistics }\end{array}$ & $\begin{array}{c}\text { P } \\
\text { value }\end{array}$ & Conclusion \\
\hline Organizational Communication -> Employee Engagement & 0.316 & 2.605 & 0.009 & Positive Significant \\
Job Satisfaction -> Employee Engagement & 0.426 & 3.933 & 0.000 & Positive Significant \\
Organizational Communication -> Employee Performance & 0.047 & 0.333 & 0.739 & Positive Not significant \\
Job Satisfaction -> Employee Performance & 0.151 & 1.176 & 0.240 & Positive Not significant \\
Employee Engagement -> Employee Performance & 0.638 & 5.574 & 0.000 & Significant positive \\
\hline
\end{tabular}

Source: Researcher processed data (2019)

Based on result shown in Table 4, it can be concluded that:

1) Organizational communication has a positive significant effect of 0.316 on employee engagement with a t-statistic value of 2.605 and P-Values of 0.009 .

2) Job satisfaction has a positive significant effect of 0.426 on on employee engagement with a t-statistic value of 3.933 and P-Values of 0,000 .

3) Organizational communication has a positive insignificant effect of 0.047 on employee performance with a t-statistic value of 0.333 and P-Values of 0.739 .

4) Job satisfaction has a positive insignificant effect of 0.151 employee performance with a $\mathrm{t}$-statistic value of 1.176 and P-Values of 0.240 . 
5) Employee engagement has a positive significant effect of 0.638 on employee performance with a t-statistic value of 5.574 and P-Values of 0.000 .

Calculation result for determination coefficient $\left(\mathrm{R}^{2}\right)$ show the value 0.470 for employee engagement and 0.603 for employee performance. Both values show that their exogenous variables have moderate determination level. In addition, predictive relevance value $\left(\mathrm{Q}^{2}\right)$ is a relevance indicator of predictive model. The calculation of $\mathrm{Q}^{2}$ is below:

$$
\begin{aligned}
& \mathrm{Q} 2=1-\left(1-\mathrm{R}^{2}\right)\left(1-\mathrm{R} 2^{2}\right) \\
& \mathrm{Q} 2=0.789
\end{aligned}
$$

The $\mathrm{Q}^{2}$ value of 0.789 , shows that the model in this research has endogenous latent variable with predictive relevance value greater than zero (0). It can be explained that the exogenous variables are able to predict the endogenous variable, which is employee performance. The other structural model evaluation is Goodness of Fit $(\mathrm{GoF})$ with the calculation below:

$$
\begin{aligned}
& \mathrm{GoF}=\sqrt{A V E} \times R^{2} \\
& \mathrm{GoF}=0.672
\end{aligned}
$$

Based on the calculation result from Goodness of Fit $(\mathrm{GoF})$ of 0.672 , it can be explained that the overall structural model is good, refer to big scale of GoF which is more than 0.36 . The

\begin{tabular}{|c|c|c|c|c|}
\hline & $\begin{array}{c}\text { Employee } \\
\text { Engagement }\end{array}$ & $\begin{array}{c}\text { Job } \\
\text { Satisfaction }\end{array}$ & $\begin{array}{l}\text { Employee } \\
\text { Performance }\end{array}$ & $\begin{array}{l}\text { Organizational } \\
\text { Communication }\end{array}$ \\
\hline Employee Engagement & 1.000 & & & \\
\hline Job Satisfaction & & 1.000 & 0.272 & \\
\hline Employee Performance & & & 1.000 & \\
\hline Organizational Communication & & & 0.202 & 1.000 \\
\hline
\end{tabular}
last evaluation done in the study is indirect effect evaluation, which is resulted from the calculate SmartPLS version 3.2.8 bootstrapping as shown in Table 5.

Table 5. Significance of Coefficient Path Indirect Effect

Source: Researcher processed data (2019)

Refer to the indirect value shown in Table 5, it can be explained that:

1) Path coefficient value of direct influence of organizational communication on employee performance 0.047 < path coefficient value of indirect influence on the teachers performance of competence is 0.202 . It is concluded that indirect effect of organizational communication on employee performance is mediated by employee engagement.

2) Path coefficient value of direct influence of job satisfaction on employee performance 0.151 < path coefficient value of indirect influence on the teachers performance of competence is 0.272 . It is concluded that indirect effect of job satisfaction on employee performance is mediated by employee engagement.

\section{Discussion}

\section{Effect of Organizational Communication on Employee Engagement (Hypothesis 1)}

Communication within an organization plays a vital role to increase engagement (Psychometrics, 2011). Based on the results of the study, it can be said that organizational communication has an influence on employee engagement, aligned with the hypothesis 
proposed by the author. Likewise, the results of this study are in line with other similar studies, where communication has a close relationship with employee engagement and is one of the factors that influence it (Minjeong and Minjung, 2017; Emma et al., 2015; Psychometrics, 2011; Chandani et al., 2016; Jiang and Men, 2015). The effect of effective organizational communication can improve employee morale and engagement, and make the organization a more pleasant workplace, so as to reduce turnover and attract more qualified employee candidates (Gillis, 2006).

The communication dimension that gets the highest response is upward communication (4.05). It can be interpreted that employees feel their communication with the direct supervisor (line manager) and project manager is good. Communication between employees and superiors occurs in the process of mentorship program, consultation and problem solving, following up on the progress of work status, feedback and suggestions for performance improvement, as well as career plans and personal development.

By knowing that the effect of organizational communication on employee engagement is positive-significant, this communication strategy must be continuously improved to ensure employee engagement at the company also continues to increase. The party most responsible for maintaining and enhancing the effectiveness of communication is the management, as the party who has the control to determine the culture, model and communication strategy to be applied (Psychometrics, 2011). A mentorship program is identified as an effective way to get employees engaged and empowered. This communication program enable organization to develop their talent and increase productivity (Purba et al., 2020).

\section{Effect of Job Satisfaction on Employee Engagement (Hypothesis 2)}

Armstrong (2006) defines job satisfaction as the attitudes and feelings people have about their work. On the other hand employee engagement is illustrated by the extent to which employees are fully involved in their work and the strength of their commitment to their work and company (Noe et al., 2016). Thus, if the company wants to have employee conditions with a positive attitude, and is committed to the work and the company, the company should promote job satisfaction by fulfilling values that are important to employees, so that high job satisfaction will help increase engagement employee to the company.

The results of respondents found from all dimensions of job satisfaction indicate some high value, especially for the dimension of work itself (3.97). Correspondingly, the effect of job satisfaction on employee engagement was found to be positive and significant $(0.426)$. The positive and significant influence of job satisfaction on engagement is reinforced by other studies from Herminingsih (2017) and Shmailan (2016). The dimension of "work itself" has the highest value, which means that employees have obtained positions and jobs that are in accordance with their interests and passions in a career, so they are enjoy in doing the assignment and work. Furthermore, the dimensions of "salary" has the lowest value, which is aligned with the result of internal engagement survey on 2018. Salary or compensation should be very well noticed by management, consider that it is identified has significant effect on employee engagement (Siahaan and Elmi, 2018).

\section{Effect of Organizational Communication on Employee Performance (Hypothesis 3)}

The results of the study concluded that organizational communication had no significant effect on employee performance. This is possible because of employee engagement variables that have a significant influence on employee performance. From the previous discussion, it is known that organizational communication has a significant influence on employee engagement. Considering the structural model in the study, it can be suspected that 
organizational communication has an influence on employee performance after being mediated by employee engagement variables.

Other research supporting the mediation process between organizational communication and performance was conducted by Yuelan and Jing (2018). In this study, organizational communication variables have a non-significant effect on performance when mediated by job satisfaction. The effect of organizational communication on job satisfaction is significant, and the effect of job satisfaction on performance is also significant. Job satisfaction acts as a comprehensive mediator variable for organizational communication and performance variables.

\section{Effect of Job Satisfaction on Employee Performance (Hypothesis 4)}

The effect of job satisfaction on employee performance, found from several studies has a high level of significance, such as Bakotic (2014), and Shmailan (2015). Bakotic (2014) argues that job satisfaction is a determinant that affects performance, not vice versa.

Based on the results of the study found that job satisfaction does not have a significant effect on employee performance. This also happens to the effect of organizational communication on employee performance. Empirical studies that support that job satisfaction does not directly affect employee performance were carried out by Ardiansyah and Purba (2015). In this research, career satisfaction variable is a mediator for the significant effect of job satisfaction on performance.

\section{Effect of Employee Engagement on Employee Performance (Hypothesis 5)}

Based on the research results, it was concluded that employee engagement had a significant effect on employee performance. This result is in line with many other studies, such as Bedarkar et al. (2014) which concluded that engagement can produce positive feelings towards employee \& organizational performance. Caplan in Shmailan (2015) also states that there is evidence that engagement can improve performance in general, create a better and productive work environment, reduce employee absenteeism and turnover. An empirical study in Indonesia conducted by Ariyanto (2018) also shows that there is a significant and positive influence between engagement and employee performance.

The implementation approach of increasing employee engagement in the workplace is designed to ensure that employees are willing to commit to their organization's values and goals, are motivated to contribute to organizational success, and are able to increase their sense of ownership in the organization simultaneously (MacLeod and Clarke, 2009). The process of how employees are engaged in producing business impact is largely determined by the company's management initiatives starting from the organization's design and job description, the process of selection and recruitment, training, compensation, performance management, and career development (Vance, 2006). The most common and expected outcomes by organizations is the higher productivity, where increased productivity is a key indicator of improved performance.

The dimension of dedication have a more dominant influence than other dimensions. Dedication can be interpreted as a feeling of strong involvement felt by someone in his work, accompanied by a high sense of and pride in his work, so he/she has enthusiasm to face challenges in his work. The dedication of Abyor employees with the majority as IT consultants, can be concluded to be high. This is in line with the high job satisfaction felt for the work dimension itself. The IT consultant employee at Abyor is already familiar with his profession, understands the goals, and values that can be contributed from the work for customers in particular, and has pride in his profession. 


\section{Employee Engagement Mediates the Effect of Job Satisfaction on Employee Performance (Hypothesis 6)}

By referring to the comparison of direct and indirect effects of organizational communication variables on employee performance, it can be said that the indirect effect of organizational communication on employee performance is mediated by employee engagement variables. In this case employee engagement can be a mediator for organizational communication variables in influencing employee performance. The higher the quality of organizational communication, the higher employee engagement, and the higher employee engagement can encourage high employee performance.

\section{Employee Engagement Mediates the Effect of Organizational Communication on Employee Performance (Hypothesis 7)}

Based on the comparison of direct and indirect effects of job satisfaction variables on employee performance, it can be said that the indirect effect of job satisfaction on employee performance is mediated by employee engagement variables. With this it can be concluded that employee engagement can be a mediator for job satisfaction variables in influencing employee performance. The higher employee job satisfaction, the higher employee engagement, and this can encourage high employee performance. These results indicate the importance of company attention in maintaining engagement to ensure high employee performance.

\section{CONCLUSION AND SUGGESTION}

With reference to the results of the research and discussion in the previous chapters, several conclusions can be made as follows:

1) Organizational communication has a positive and significant effect on employee engagement. The dimension of communication to the top has the strongest influence among others.

2) Job satisfaction has a positive and significant effect on employee engagement, with the job dimension itself giving the greatest influence among other dimensions.

3) Organizational communication has no significant effect on performance.

4) Job satisfaction does not significantly influence performance.

5) Employee engagement has a positive and significant influence on employee performance. Dedication has the highest effect among others.

6) Employee engagement becomes a mediator for organizational communication variables in influencing employee performance.

7) Employee engagement becomes a mediator for job satisfaction variables in influencing employee performance.

Finally, based on the results of the analysis of the discussion and some of the conclusions above, the suggestions that can be given to supplement the results of this study are as follows:

1) Safeguarding and enhancing upward communication that is already going well. The culture of people development that is already running needs to be developed. In addition to mentoring activities, other people development approaches can be carried out such as coaching and training.

2) High job satisfaction arises from dimension of the work itself which can be enhanced by ensuring the recruitment process, specifically the matching process between job description and the interests and potential candidates applying for the position. Various assessment models can be considered to ensure the matching process. The lowest 
dimension score from job satisfaction is salary, which is aligned with the internal engagement survey result. Considering the competitive talent war in IT industry, management should review to propose more attractive salary and compensation in accordance with the market rate, so it can ensure their employee keep engaged.

3) Seeing the importance of employee engagement, management needs to enhance it by some programs, such as effective employee onboarding processes, by providing an introduction to the company's philosophies and values, company's overall business, code of conduct, mentoring by mentors to assist employees in undergoing the process of adapting to the company's environment, as well as effective support and communication from superiors regarding the assignment given.

\section{REFERENCE}

Ardiansyah, Ferdy; Purba, Sylvia Diana. (2015). "Pengaruh Kepuasan Kerja Terhadap Kinerja Guru Dengan Motivasi Karir Sebagai Variabel Moderasi dan Kepuasan Karis Sebagai Variabel Mediasi Padaa YP IPPI”. DeReMa Jurnal Manajemen, Vol.10, No.1

Armstrong, Michael. (2006). A Handbook of Human Resource Management Practice. Kogan Page, London.

Armstrong, Michael and Angela Baron. (1998). Performance Management - The New Realities. Institute of Personnel and Development. London

Ariyanto, Dian. (2018). "Pengaruh Coaching, Employee Engagement dan Kepuasan Kerja Terhadap Kinerja Pegawai Di PT Bank Central Asia Kedoya Permai, Jakarta Barat”. Thesis. Magister Manajemen, Program Pascasarjana, Mercubuana University, Jakarta.

Baba, Ali. (2014). "Pengaruh Kompetensi, Komunikasi dan Budaya Organisasi Terhadap Kinerja Karyawan PT. Semen Bosowa Maros". Ekuitas: Jurnal Ekonomi dan Keuangan, Vol. 18 , No. 4, pg. $524-540$. 